\section{Organizational characteristics and COVID-19 safety practices among small and medium construction enterprises (SMEs) in Nigeria}

COVID-19 safety practices among SMEs

Samuel Abiodun Alara

Department of Quantity Surveying, School of Environmental Science Technology, Federal Polytechnic, Mubi, Nigeria

\begin{abstract}
Purpose - The deadly nature of the coronavirus (COVID-19) has severe consequences on human health and the global economy. There are rising numbers of COVID-19 cases despite containment measures. Organizations differ in their strategic responses to institutional forces. This study investigates the role of organizational characteristics in shaping COVID-19 safety practices among small and medium construction enterprises (SMEs) in Nigeria.

Design/methodology/approach - A quantitative research approach was employed through exploratory and descriptive designs. The study questionnaires were administered to 362 active construction SMEs which were randomly sampled from the list of 6,364 SMEs registered with the corporate affairs commission in Lagos, 296 were used for analysis; corresponding to an $82 \%$ response rate. Factor analysis was used to reduce 9 COVID-19 safety practices to 3 core practices used for further analysis. Multiple regression was employed to determine the relationship between organizational characteristics and COVID-19 safety practices.

Findings - Results show that SMEs workforce, annual turnover and total asset have a positive and significant relationship with COVID-19 safety practices, while SMEs' area of specialization is a poor predictor. It was concluded that organizational characteristics play a significant role in shaping COVID-19 safety practices among SMEs

Research limitations/implications - The study is limited to only five organizational characteristics; new variables could be examined in the future.

Originality/value - This study shows that organizational characteristics can shape COVID-19 safety practices among SMEs. Findings will assist procuring entities in their decision to award construction contracts during the pandemic.
\end{abstract}

Keywords COVID-19, Organizational characteristics, SMEs safety practices, Construction sites, Institutional theory

Paper type Research paper

\section{Introduction}

Coronavirus (COVID-19) emerged in China, in December 2019 and has since spread across the globe (Preskorn, 2020, p. 220; World Health Organization (WHO), 2021). The COVID-19 pandemic has infected over 119 million people and caused over 2.6 million deaths globally (WHO, 2021). Africa recorded more than 4 million confirmed cases and over 100,000 deaths

(C) Samuel Abiodun Alara. Published in Frontiers in Engineering and Built Environment. Published by Emerald Publishing Limited. This article is published under the Creative Commons Attribution (CCBY 4.0) licence. Anyone may reproduce, distribute, translate and create derivative works of this article (for both commercial and non-commercial purposes), subject to full attribution to the original publication and authors. The full terms of this licence may be seen at $\mathrm{htt}$ ://creativecommons.org/licences/by/4.0/legalcode

The author wishes to express his profound gratitude to staff members of Y.S Associates Ltd for their assistance throughout the period of the study. The author expresses his most sincere gratitude to QS. Yusuf Shawulu FNIQS; Principal Partner of Y.S Associates for his generosity and encouragement in all aspects of the study.

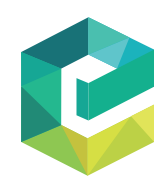

Frontiers in Engineering and Built Environment Vol. 1 No. 1,2021 Emerald Publishing Limited e-ISSN: 2634-2502 p-ISSN : 2634-2502 DOI 10.1108/FEBE-02-2021-0006 
FEBE 1,1

with Nigeria reporting more than 160,000 cases of COVID-19 and over 2,000 deaths (WHO, 2021). According to WHO (2020), COVID-19 spreads primarily through respiratory droplets or contact with contaminated surfaces. Exposure can occur at the workplace while traveling to work and during work-related travel to an area with local community transmission. These could lead to the viral transmission of person to person when individuals are near one another. Typically, this implies that the entire human population is potentially susceptible to COVID-19 infection (Preskorn, 2020, pp. 219-221). According to Hyams et al. (2002, pp. 274-280), the concern associated with the deadly virus such as COVID-19 is similar to the reaction of biological and other terrorism threats and causes a high level of stress, often with longer-term devastating consequences. In handling a pandemic, its spread must be contained to reduce the impact on the economy and the society, reducing morbidity and mortality (Hyams et al., 2002, pp. 274-280). Efforts to accommodate the new way of life occasioned by the advent of the COVID-19 pandemic necessitated studies on the adaptability, effects and prospects, consequences, potential risks, control measures and impacts of COVID-19 on the construction sector (Al Amri and Marey-Pérez, 2020; Ezeokoli et al., 2020; Gbadamosi et al., 2020; Hollingsworth, 2020; Ogunnusi et al., 2020; Shibani et al., 2020; Simpeh and Amoah, 2021). The global economy has been disrupted since the beginning of the pandemic (International Labour Organization (ILO), 2020; McKibbin and Fernando, 2020, p. 15). When COVID-19 infection runs out of control it results in a total lockdown of all human activities and as such, disrupts the small and medium construction enterprises (SMEs) of any infected nation from playing its role as an important economic force (Abada and Okorie, 2016, p. 298; ILO, 2020; Kamal and Flanagan, 2014, p. 1; Small and Medium Enterprises Development Agency Of Nigeria (SMEDAN) and National Bureau of Statistics (NBS), 2017, pp. 5-6).

In response to combating COVID-19 transmission, countries are imposing a range of prevention and containment measures against the spread of the pandemic and SMEs are facing regulatory and nonpharmaceutical interventions (Brooks and Knights, 2020; Lexisnexis, 2020; WHO, 2020). In Nigeria, the Federal Government signed the COVID-19 Disease Health Protection 2021 and imposed COVID-19 guidelines at construction sites (Brooks and Knights, 2020; Federal Republic of Nigeria (FRN), 2021; Gbonegun, 2020). Despite these rules, there are still increasing confirmed cases of COVID-19 across the globe, with some countries having "second waves" of increased cases triggered by laxity in adopting COVID-19 safety practices among SMEs (Maragakis, 2020). For instance, In South Africa, only $47 \%$ of SMEs in the public sector were likely to adopt COVID-19 safety practices compared to $57 \%$ of their counterparts in the private sector (Lexisnexis, 2020). Conversely, in Nigeria, the response to the COVID-19 safety practices on construction sites falls short of expectation (Ezeokoli et al., 2020, p. 76; Gbadamosi et al., 2020, p. 4). Recent studies revealed that inadequately protected workspace can form COVID-19 clusters and viral transmission (ILO, 2020; WHO, 2020). Institutional theory has been projected to be a suitable lens for examining the dynamics of organizational strategic responses to regulations (Moser et al., 2020; Raynard et al., 2015). This will assist in investigating the underlying dynamics of COVID-19 safety practices and the influence of organizational characteristics which are expressed based on their total assets, workforce, annual turnover, years of establishment and area of specialization of SMEs. Organizations differ in their strategic responses to institutional forces; organizations may decide to avoid, compromise, defy and manipulate the institutional environment based on organizational characteristics (Lama and Anderson, 2015; Moser et al., 2020; Oliver, 1991; Raynard et al., 2015; Shittu et al., 2016). However, a review of studies conducted on COVID-19 safety management falls short of explaining the role of organizational characteristics in shaping the attitudes of SMEs toward COVID-19 safety practices (Al Amri and Marey-Pérez, 2020; Ezeokoli et al., 2020; Gbadamosi et al., 2020; Hollingsworth, 2020; Ogunnusi et al., 2020; Shibani et al., 2020; Simpeh and Amoah, 2021). 
Hence, this study investigates the role of organizational characteristics in shaping COVID-19 safety practices among SMEs to prevent the transmission of COVID-19 in Nigeria.

\section{Literature review}

\subsection{COVID-19 safety practices}

The devastating nature of COVID-19 has severe consequences on human health and the global economy (ILO, 2020; McKibbin and Fernando, 2020, pp. 15-16). This is reflected in reduced consumption of various goods and services, a hike in business operating costs, the disruption of labor supply and a rise in risk premiums (ILO, 2020; McKibbin and Fernando, 2020, pp. 15-16). Specifically, the pandemic has disrupted the construction industry workflows and supply chain. Other effects include workplace closures, poor economic prospects, travel restrictions, low productivity, job losses, workers anxiety and hardship, rise in H\&S management budget and high cost of operations (Al Amri and MareyPérez, 2020; Gbadamosi et al., 2020; International Labour Organization, 2020; Ogunnusi et al., 2020, p. 127; Shibani et al., 2020). As countries experience a steady increase in the number of confirmed cases of COVID-19 infections, movement restrictions and lockdowns are being instituted (Maragakis, 2020; Ogunnusi et al., 2020, p. 124). The WHO (2020) and ILO (2020) issued guidance on occupational health and safety $(\mathrm{H} \& \mathrm{~S})$ measures to adequately respond to the COVID-19 pandemic globally. The construction industry like many other industries is being transformed to meet the new demands of the pandemic era through the adaption of work arrangements, the application of modern procurement planning, virtual working, unique design consideration, management of stress and other psychosocial risks (ILO, 2020; Ogunnusi et al., 2020). Similarly, in Nigeria, the authorities acknowledged the urgent need to protect the health and wellbeing of workers on construction sites in the face of the widespread and rising numbers of COVID-19 cases in the country. Consequently, the Federal Government signed the COVID-19 Disease Health Protection 2021 (FRN, 2021). This regulation mandates the use of face mask in workplaces, places restrictions on gathering, required a physical distance of at least $2 \mathrm{~m}$ between workers, restrict more than 50 persons in an enclosed space, permit access to only critical personnel on-site and prohibit a worker with body temperature above 38 degrees Celsius entry to the site and such worker be advised to immediately seek medical attention. The setting of the construction site that brings workers together puts them at high risk of exposure to COVID-19 (Hollingsworth, 2020, p. 32). To curb the risk of COVID-19 on construction workers, construction SMEs are required to adopt COVID-19 safety practices, as well as integrate them into the implementation of business continuity plans (Gbonegun, 2020; Lexisnexis, 2020; Ogunnusi et al., 2020, p. 122). In line with COVID-19 global response strategies for the workplace and the Federal Government of Nigeria COVID-19 regulation, the basic requirements for COVID-19 safety practices to be observed by SMEs at all active construction sites are summarized below:

(1) To implement a two-phase screening process; phase one being an initial declaration and phase two ongoing daily screening through a non-contact method.

(2) Carryout and regularly update the risk assessment for work-related exposure to COVID-19, preferably with the support of occupational health services.

(3) Develop action plans to prevent and mitigate COVID-19 as part of the business continuity plan and according to the results of the risk assessments and the epidemiological situation.

(4) Maintain flexible sick leave policies to discourage workers with symptoms consistent with COVID-19 from coming to the workplace.

COVID-19 safety practices among SMEs 


\section{FEBE \\ 1,1}

(5) If a worker declares symptoms consistent with COVID-19; such a worker should be required to self-isolate.

(6) To conduct temperature screening on all workers before admission to the construction site.

(7) To record the schedule and work locations for workers which will enable tracking of those who have come into contact with any confirmed case

(8) To maintain a physical distancing of at least $2 \mathrm{~m}$ between workers on construction sites. SMEs should consider a safe alternative way to undertake each task with an increased distance between workers.

(9) To stagger start times breaks and finish times to avoid congestion in high traffic areas and minimize workers coming into contact with each other as they move around the site.

(10) To install temporary physical barriers (e.g. fences, screens) between work areas, where appropriate.

(11) To promote the culture of regular handwashing with soap for at least $20 \mathrm{~s}$, use hand sanitizers, good cough etiquette by covering your cough and sneeze, or cough into your elbow or shoulder, avoid touching your nose, eyes, or mouth.

(12) To ensure that workers maintain good hygiene by providing access to soap and running water on all sites for frequent handwashing, preferably at the site entrance, at the meal area and close to the toilet facilities.

(13) To ensure employees avoid the sharing of office stationaries, the shared use of tools, plants and equipment and be regularly disinfected.

(14) To provide, train and instruct employees on the safe use, decontamination and maintenance of personal protective equipment (PPE).

(15) To update site inductions to include information on COVID-19 potential risks and specific controls.

(16) To conduct toolbox talks regularly; to provide clarity and encourage self-reporting to minimize the spread of COVID-19.

(17) Reduce in-person meetings and other gatherings and hold site meetings in open spaces or outdoor.

\subsection{Organizational characteristics used to define SMEs}

Organizational characteristics are the unique attributes or distinguishing features that define an organization or a corporate entity (Chinowsky et al., 2007, p. 31; Okafor, 2007, p. 38). Studies have adopted different criteria as organizational characteristics to define or determine the performance of SMEs. For instance, Olokoyo (1999) classify SMEs by the average annual turnover, area of specialization, the number of skilled and unskilled labor, coverage of the operation, the number of full-time employees, company structure, the collected company worth, major clients of the firms, year of establishment, sources of equipment, the company registration grade, sources of project finance, tendering procedure for securing contracts and procurement method adopted by these firms. Shittu et al. (2016, p. 61) defined SMEs based on the firm's experience, annual turnover, number of employees and construction type. Okafor (2007, p. 38) on the other hand, adopted the 4S (staff, styles, skills and shared value) as distinguishing features. Similarly, Ayyagari et al. (2007, 
pp. 416-421) defines SMEs by the number of employees, registration, turnover and shares the type of works they undertake. Kamal and Flanagan (2014, p. 7) in the classification of SMEs used technology and training, ownership structure, labor force and political exposure. Others include; managerial style, net worth, turnover, levels of capitalization, profitability, source of capital, the scope of operation; major client of the firms, sector, paid-up capital, size, technology, location, assets, specialization (building and engineering); growth rate, size and category of contracts, organization type, the nationality of the company's owner(s), capital requirements, skills and levels of industrial development, project funding arrangement and management control (Abada and Okorie, 2016; Ayyagari et al., 2007; Kamal and Flanagan, 2014; Ogunnusi et al., 2020, p. 122; Okafor, 2007; SMEDAN and NBS, 2017)

Similarly, SMEDAN (2015), classify small enterprise as organizations with a total asset, including working capital but excluding the cost of land and building; is between N5 million and N50 million and workforce between 10 and 49 full-time workers and an annual turnover of not more than N10 million, while medium enterprise as an organization with a total asset, including working capital but excluding the cost of land and building; of over N50 million, but less than N500 million and workforce between 50 and 199 full-time workers, with an annual turnover of not more than N20 million. In addition to SMEs' years of establishment and area of specialization, this study adopted classifications of SMEs by SMEDAN (2015) because they are considered worthwhile and more encompassing.

\subsection{Conceptual model}

This study builds on institutional theory to investigates the role of organizational characteristics in shaping COVID-19 safety practices among SMEs in Nigeria. Institutional theory postulates that "organizations respond to pressures arising from their external and internal business environments and adopt structures and practices that are accepted as appropriate organizational choices and considered legitimate by other organizations in their fields" (DiMaggio and Powell, 1983; Meyer and Rowan, 1977; Zucker, 1987). DiMaggio and Powell (1983) classify these pressures into three; the emergence of new rules enacted by the state can propel organizational strategic response (coercive pressures), secondly, pressures arising from the need to copy successful competitors during periods of high uncertainty can propel organizational change (mimetic pressures) and thirdly, pressures as a result of norms in certain vocation (normative pressures). These pressures guide organizations toward isomorphism. As new practices are increasingly adopted, they attain a level of legitimization where failure to adopt them is seen as irrational as such organizations adopt these practices to show conformity and gain legitimacy to ensure organizational survival (Zucker, 1987). Studies revealed that although the central idea of institutional theory is isomorphic behavior, organizations differ in their strategic responses to institutional forces, organizations may decide to avoid, compromise, defy and manipulate the institutional environment based on organizational characteristics. (Lama and Anderson, 2015; Moser et al., 2020; Oliver, 1991; Shittu et al., 2016). Institutional theory has been projected to be a suitable lens to examine the dynamics of organizational strategic responses to regulations (Moser et al., 2020; Raynard et al., 2015). In response to combating COVID-19 transmission SMEs are facing regulatory and nonpharmaceutical interventions to curtail the spread of the pandemic (e.g. FRN, 2021; ILO, 2020; WHO, 2020). Institutional theory will assist in investigating the role of organizational characteristics; expressed as SMEs years of establishment, workforce, annual turnover, total assets and area of specialization, in shaping COVID-19 safety practices in terms of management commitments, workers commitments and safety education and training among SMEs. Within the context of Institutional theory, COVID-19 safety requirements and organizational characteristics are pressures that both interact to stimulate SMEs toward adopting safety practices to prevent transmission of COVID-19. Accordingly, a conceptual model was developed building on institutional theory to examine
COVID-19 safety practices among SMEs 
FEBE 1,1

Figure 1.

Conceptual model the role of organizational characteristics in shaping COVID-19 safety practices among SMEs (see Figure 1) in light of the aforementioned, the following hypotheses are proposed:

H1. There is a relationship between organizational characteristics and SMEs COVID-19 management commitments.

H2. There is a relationship between organizational characteristics and SMEs COVID-19 workers' commitments.

H3. There is a relationship between organizational characteristics and SMEs COVID-19 safety education and training.

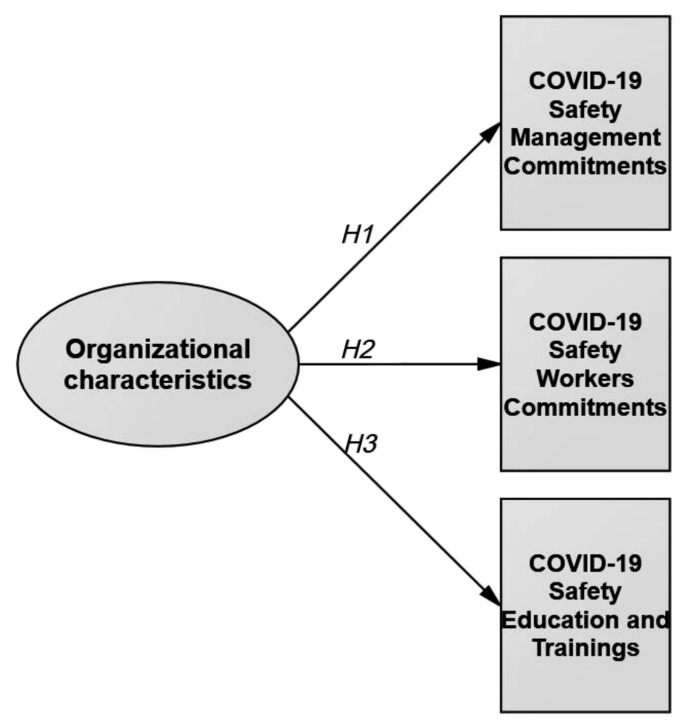

Effects of organizational characteristics on COVID-19 Safety Practices

\section{Methodology}

A quantitative research approach through exploratory and descriptive designs was employed to investigate the role of organizational characteristics in shaping COVID-19 safety practices among SMEs in Nigeria, in line with the recommendation of McNabb (2020, pp. 96-108). The global response strategies on COVID-19 for the workplace and related works of literature were reviewed to gain insight into the study constructs (McNabb, 2020, pp. 96-108). A structured questionnaire was developed to collect data via an online medium. Online questionnaire surveys have some advantages over field distribution, such as timesaving and access to unique populations (McNabb, 2020, pp. 96-108). More so, online questionnaire surveys were preferred over field distribution because of the need to maintain a non-contact strategy as required by COVID-19 protocols (FRN, 2021). The questionnaire was segmented into three sections to address questions on respondents' demographics, organizational characteristics and attitudes toward COVID-19 safety practices. The questionnaire was pre-tested by 3 professors of ergonomics, 5 core professionals who are 
experts in H\&S management and 15 active SMEs with wide experience in the construction industry. This was done to identify possible errors, ensure correct wordings and improve the reliability of the questionnaire (Fornell and Larcker, 1981; McNabb, 2020). The organizational characteristics investigated include total asset, workforce, annual turnover, years of establishment and area of specialization. The final questionnaire contained 14 statements on COVID-19 safety practices. The statements were written in both positive and negative tone to reflect SMEs COVID-19 management commitments, workers commitments, COVID-19 safety training and education because these dimensions addressed the H\&S core practices area and H\&S tripartite constituents (ILO, 2020; Shittu et al., 2016, pp. 62-63). The respondents were requested to indicate the extent to which they adopt COVID-19 safety practices using a 5point Likert scale where 5 indicates very high and 1 indicates very low. The study questionnaires were administered to 362 active construction SMEs which were randomly sampled from the list of 6,364 SMEs registered with the corporate affairs commission in Lagos using the Krejcie and Morgan (1970) table. Out of 362 questionnaires, 296 were retrieved and used for analysis; corresponding to an $82 \%$ response rate (SMEDAN and NBS, 2017).

\subsection{Data analysis}

Descriptive and inferential statistics were used to interpret the data. Factor analysis with principal components extraction was employed to examine the data set, to identify complicated interrelationships and underlying variables among items (Field, 2018). This was done to examine whether the statements represent identifiable factors related to COVID-19 safety practices and cluster similar variables into the same factor. In line with the recommendations of Field (2018), McNabb (2020) and Shrestha (2021), Kaiser-Meyer-Olkin's (KMO) measure of sampling adequacy and Bartlett's test of sphericity were used to assess the suitability of the data for factor analysis. The determinant score was calculated to assess the multicollinearity among the study variables. Kaiser's criterion (eigenvalue criterion) and Scree plot were used to determine the number of factors to be extracted. Varimax orthogonal factor rotation method was used to facilitate interpretation of factor loadings. The reliability and validity tests of the scales were conducted by Cronbach's alpha coefficient, average variance extracted (AVE) and composite reliability (CR). Hypotheses were tested using multiple regression analysis. Factorized COVID-19 safety practices were regressed on organizational characteristics. Organizational characteristics were divided into two groups of "base case" and "others" using dummy variable coding 0 and 1 . This was done to transform the data from categorical to dichotomous data. Organizational characteristics in terms of total assets (5-20 million and 21 to 49 million), area of specialization (building), years of experience (less than 20 years), staff strength (10-49 employees) and turnover (2-5 million and 5 to 10 million) were treated as "base case" (denoted by 0 ) while the remaining were treated as "other group" (denoted by 1). Regression coefficients were tested with a $t$-statistic. The coefficient of determination $\left(R^{2}\right)$ was used as an indicator of the quality of the regression and the level of significance of $p<0.05$ and $p<0.01$ were adopted (Field, 2018). The preliminary investigation carried out indicated that the assumptions of normality, linearity, multicollinearity, sample adequacy, factorability and homoscedasticity of residuals were not violated. All the statistical analysis was performed using IBM SPSS version 26 and Microsoft Excel.

\section{Results and discussions}

Table 1 shows the respondents' demographics and SMEs' organizational characteristics. Results show that seventy-eight percent of the respondents are male while twenty-two percent are female. Over $75 \%$ of the respondents belong to the top management level and have work experience in the range of $11-20$ years. In total, $64 \%$ of the respondents are either holders of Bachelor of Science or higher national diploma; $23 \%$ hold either Master of Science 
FEBE 1,1

\section{8}

\section{Table 1.}

Respondents'

demographics and

SMEs' organizational characteristics or technology, and $13 \%$ of the respondents are holders of Ph.D. Their professional discipline is either project management $(25 \%)$, H\&S management (25\%), quantity surveying $(13 \%)$, architecture $(13 \%)$, building $(18 \%)$, or engineering $(6 \%)$. Respondents' management levels, work experience, educational qualification and professional discipline show that they are fit and capable to supply reliable data for this study. $51 \%$ of the organizations surveyed have been established in less than 20 years, while $49 \%$ have been in operation for over 20 years. Their operational specialization is either in the building $(50 \%)$ and civil engineering $(50 \%)$ works. 51\% have their workforce range between 10 and 49 while the remaining $49 \%$ have between 50 and 199 employees. Annual turnovers are $2-5$ million (19\%), 5 to 10 million ( $31 \%)$, 10 to 15 million (24\%), 15 to 20 million (26\%). Their total assets, including working capital but excluding the cost of land are 5-20 million (25\%), 21 to 49 million (26\%), 50 to 250 million $(25 \%)$ and 251 to 499 million (24\%). In other words, a hundred percent of the organizations surveyed have total assets in the range of 5-499 million, workforce range between 10 and 199 employees and annual turnover range between 2 and 20 million. This shows that the organizations sampled are SMEs and possessed the organizational characteristics that were adopted in this study (see Table 1).

\begin{tabular}{|c|c|c|c|c|c|c|c|}
\hline \multicolumn{4}{|c|}{ Respondents demographics } & \multicolumn{4}{|c|}{ SMEs' organizational characteristics } \\
\hline & & & & & & & \\
\hline \multirow{3}{*}{ Gender } & & & & Total assets & & & \\
\hline & Male & 230 & 78.0 & & 5 to 20 million & 73 & 25.0 \\
\hline & Female & 66 & 22.0 & & 21 to 49 million & 76 & 26.0 \\
\hline \multirow[t]{4}{*}{ Status } & & & & & 50 to 250 million & 75 & 25.0 \\
\hline & Low management & 19 & 6.0 & & 251 to 499 million & 72 & 24.0 \\
\hline & Middle & 53 & 18.0 & Workforce & & & \\
\hline & Top management & 224 & 76.0 & & 10 to 49 & 151 & 51.0 \\
\hline \multirow[t]{4}{*}{ Experience } & & & & & 50 to 199 & 145 & 49.0 \\
\hline & Less than 10 & 16 & 5.0 & Specialization & & & \\
\hline & $11-20$ years & 224 & 76.0 & & Building & 148 & 50.0 \\
\hline & Over 20 years & 56 & 19.0 & & Civil & 148 & 50.0 \\
\hline \multirow[t]{4}{*}{ Qualification } & & & & Establishment & & & \\
\hline & HND/B.Sc & 189 & 64.0 & & Less than 20 years & 151 & 51.0 \\
\hline & M.Sc/MTech & 69 & 23.0 & & Over 20 years & 145 & 49.0 \\
\hline & $\mathrm{Ph} . \mathrm{D}$ & 38 & 13.0 & Turnover & & & \\
\hline \multirow[t]{7}{*}{ Specialization } & & & & & 2 to 5 million & 55 & 19.0 \\
\hline & Project management & 73 & 25.0 & & 5 to 10 million & 91 & 31 \\
\hline & H\&S management & 73 & 25.0 & & 10 to 15 million & 73 & 24.0 \\
\hline & Building & 54 & 18.0 & & 15 to 20 million & 77 & 26.0 \\
\hline & Quantity surveying & 39 & 13.0 & & & & \\
\hline & Architecture & 38 & 13.0 & & & & \\
\hline & Engineering & 19 & 6.0 & & & & \\
\hline
\end{tabular}

\subsection{Factor analysis for COVID-19 safety practices}

Preliminary investigation revealed a KMO of 0.747 , Bartlett's test of sphericity $p<0.000$ and a determinant score of 0.175 . This is in line with the recommendation of Kaiser (1970) that KMO benchmark value of $>0.60$, Bartlett's test of sphericity $p<0.000$ and the determinant score of the correlation matrix should be $>0.00001$ (Bartlett, 1951). The results indicate that the data are suitable for factor analysis. Eigenvalue criterion and Scree plot suggest a three factors solution (eigenvalue $>1$ ). Although the finalize questionnaire contained 14 statements on COVID-19 safety practices, however, 5 items were removed to address the issue of crossloading. Table 2 show the analysis generated three factors explaining a total of $59.59 \%$ of the 
variance for the study variables which is above the benchmark of at least $50 \%$ as recommended by Shrestha (2021, p. 9). The bold marked indicate the items loading for each factor. Item 1-4 loaded into Factor 1 and labeled "SMEs COVID-19 Management Commitments" because it bears semblance with practices required of SME'S management. This factor explained $23.00 \%$ of the variance with eigenvalue 2.07 . Item 5-7 loaded into Factor 2 and named "SMEs COVID-19 Workers Commitments" because it bears semblance with practices required of SME's workers. The second factor explained $20.31 \%$ of the variance with eigenvalue 1.83. item 8-9 loaded into factor 3 and labeled "COVID-19 Safety Education and Training" because it relates to training and education practices. The third factor explained $16.28 \%$ of the variance with eigenvalue 1.47 . The factor loadings for all COVID-19 safety practices were $>0.4$ and yielded acceptable communalities as suggested by McNabb (2020), Field (2018) and Shrestha (2021, p. 9).

\begin{tabular}{|c|c|c|c|c|c|}
\hline \multirow[t]{2}{*}{$\mathrm{S} / \mathrm{N}$} & \multirow[t]{2}{*}{ Variables } & \multicolumn{3}{|c|}{ Rotated factor loadings } & \multirow[t]{2}{*}{ Communality } \\
\hline & & Factor 1 & Factor 2 & Factor 3 & \\
\hline & SMEs COVID-19 management commitments & & & & \\
\hline 1 & Provision of soap and running water/sanitizer & 0.747 & 0.014 & 0.117 & 0.572 \\
\hline 2 & Implement a two-phase screening process & 0.709 & 0.050 & 0.046 & 0.507 \\
\hline 3 & Risk assessment for work-related exposure & 0.668 & 0.145 & 0.240 & 0.524 \\
\hline \multirow[t]{2}{*}{4} & Maintain flexible sick leave policies & 0.617 & 0.170 & 0.153 & 0.433 \\
\hline & SMEs COVID-19 workers commitments & & & & \\
\hline 5 & Wear personal protective equipment (PPE) & 0.200 & 0.839 & -0.047 & 0.746 \\
\hline 6 & Maintain physical distancing & 0.197 & 0.781 & 0.078 & 0.655 \\
\hline \multirow[t]{2}{*}{7} & Participate in training provided by the employer & -0.060 & 0.666 & 0.179 & 0.480 \\
\hline & COVID-19 safety education and training & & & & \\
\hline 8 & Site inductions on COVID-19 risks and controls & 0.118 & 0.118 & 0.849 & 0.749 \\
\hline \multirow[t]{4}{*}{9} & Educate workers on self-reporting and isolation & 0.294 & 0.064 & 0.779 & 0.698 \\
\hline & Eigenvalue & 2.070 & 1.828 & 1.465 & \\
\hline & $\%$ of Total variance & 23.001 & 20.309 & 16.278 & \\
\hline & Total variance & & & $59.588 \%$ & \\
\hline
\end{tabular}

COVID-19 safety practices among SMEs

\subsection{Reliability and validity test results}

Table 3 revealed Cronbach's alpha values $0.72,0.71$ and 0.70 , respectively, for the study constructs and 0.73 for the overall scale items which is greater than 0.70 as recommended by McNabb (2020). This confirms the reliability of the survey instrument. Table 3 further revealed composite reliability higher than 0.6. According to Fornell and Larcker (1981, p. 46), if AVE is less than 0.5, but composite reliability is higher than 0.6 , the convergent validity of the construct is still adequate. The composite reliability values for the study constructs are $0.78,0.81$ and 0.80 , respectively. This confirms convergent validity for the study constructs and evidence of internal consistency in the scale items.

\begin{tabular}{lcrr}
\hline Constructs & Reliability (Cronbach's alpha) & AVE & CR \\
\hline SMEs COVID-19 management commitments & 0.72 & 0.47 & 0.78 \\
SMEs COVID-19 workers commitments & 0.71 & 0.59 & 0.81 \\
COVID-19 safety education and training & 0.70 & 0.66 & 0.80
\end{tabular}

Table 3.

Reliability, average variance extracted (AVE) and composite reliability (CR) 
FEBE 1,1

\section{0}

Table 4.

Effects of organizational characteristics on COVID-19 safety management commitments

\subsection{Effects of organizational characteristics on SMEs COVID-19 management commitments}

Table 4 shows the effect of organizational characteristics on SMEs COVID-19 management commitments. The R2 value of 0.29 indicated that organizational characteristics explained $29 \%$ variance in the SMEs COVID-19 management commitments with $F(5,290)=23.645$, $p<0.01$. The findings revealed that annual turnover $(\beta=0.539, p<0.01)$ and workforce $(\beta=0.382, p<0.01)$ positively predicted COVID-19 management commitments among SMEs. The results show that years of establishment $(\beta=-0.403, p<0.01)$ has a significant negative linear relationship with COVID-19 management commitments among SMEs whereas asset $(\beta=0.033, p=0.656)$ and area of specialization $(\beta=-0.080, p=0.292)$ has a non-significant effect on COVID-19 management commitments among SMEs. Findings further revealed the model tested is significant at $p<0.01$ thus, there is significant evidence to conclude that there is relationship between organizational characteristics and SMEs COVID-19 management commitments.

\begin{tabular}{lrcrrrrr}
\hline & & & \multicolumn{4}{c}{$\begin{array}{c}9 \% \text { Confidence } \\
\text { interval }\end{array}$} & Model Sig. $(p)$ \\
Variables & $B$ & Std. error & $\beta$ & $t$ & Lower & Upper & 0.000 \\
\hline (Constant) & 2.649 & 0.066 & & 39.992 & 2.519 & 2.779 & 0.000 \\
Asset & 0.054 & 0.121 & 0.033 & 0.446 & -0.184 & 0.293 & 0.656 \\
Specialization & -0.130 & 0.123 & -0.080 & -1.057 & -0.371 & 0.112 & 0.292 \\
Workforce & 0.620 & 0.099 & 0.382 & 6.262 & 0.425 & 0.815 & 0.000 \\
Establishment & -0.654 & 0.126 & -0.403 & -5.198 & -0.901 & -0.406 & 0.000 \\
Turnover & 0.875 & 0.188 & 0.539 & 4.656 & 0.505 & 1.245 & 0.000 \\
Note(s): $R$ square & $=0.29$ & & & & & & \\
\end{tabular}

\subsection{Effects of organizational characteristics on SMEs COVID-19 workers commitments}

Table 5 shows the effect of organizational characteristics on SMEs COVID-19 workers commitments. The $\mathrm{R} 2$ value of 0.42 indicated that organizational characteristics explained $42 \%$ variance in the SMEs COVID-19 workers commitments with $F(5,290)=41.168, p<0.01$. The findings revealed that workforce $(\beta=0.462, p<0.01)$ positively predicted COVID-19 workers commitments among SMEs whereas annual turnover $(\beta=0.040, p=0.705)$, years of establishments $(\beta=0.124, p=0.079)$, asset $(\beta=0.043, p=0.528)$ and area of specialization $(\beta=0.105, p=0.128)$ have a non-significant effect on COVID-19 workers commitments among SMEs. Findings further revealed the model tested is significant at $p<0.01$ thus, there is significant evidence to conclude that there is a relationship between organizational characteristics and SMEs COVID-19 workers commitments.

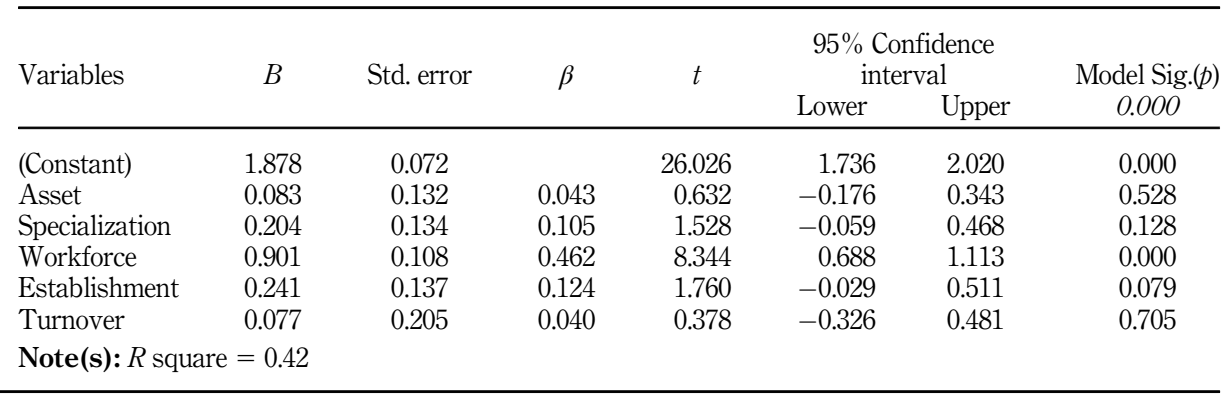

Note(s): $R$ square $=0.42$
Table 5.

Effects of organizational characteristics on COVID-19 workers commitments 
4.5 Effects of organizational characteristics on COVID-19 safety education and training

Table 6 shows the effect of organizational characteristics on COVID-19 safety education and training. The $R^{2}$ value of 0.26 indicated that organizational characteristics explained $26 \%$ variance in the SMEs COVID-19 safety education and training with $F(5,290)=20.618$, $p<0.01$. The findings revealed that annual turnover $(\beta=0.484, p<0.01)$, workforce $(\beta=0.272, p<0.01)$ and asset $(\beta=0.170, p=0.026)$ positively predicted COVID-19 safety education and training among SMEs. The results show that years of establishment $(\beta=-0.411, p<0.01)$ has a significant negative linear relationship with COVID-19 safety education and training among SMEs whereas the area of specialization $(\beta=-0.059$, $p=0.442$ ) has a non-significant effect on COVID-19 safety education and training among SMEs. Findings further revealed the model tested is significant at $p<0.01$ thus, there is significant evidence to conclude that there is a relationship between organizational characteristics and SMEs COVID-19 safety education and training.

The results in Tables 4, 5 and 6 revealed that all organizational characteristics except SMEs' area of specialization play significant roles in shaping COVID-19 safety practices as it relates to management commitments, workers commitments, COVID-19 safety education and training. The negative predictive values of the years of establishment showed that SMEs' COVID-19 management commitments and COVID-19 safety education and training declined with an increase in years of establishment. Likewise, SME management and workers' commitments to COVID-19 safety practices improved with an increase in workforce and annual turnover. COVID-19 safety education and training practices among SMEs improved with an increase in SMEs workforce, annual turnover and assets. Similarly, findings revealed SMEs' annual turnover has the highest predictive value which means that it makes the most significant contribution to COVID-19 safety practices among SMEs than other predictors. Other predictors; include workforce, years of establishment and assets of SMEs. The findings of this study align with Lama and Anderson (2015), Okafor (2007), Shittu et al. (2016) and consistent with institutional theory (DiMaggio and Powell, 1983; Meyer and Rowan, 1977; Oliver, 1991; Zucker, 1987).

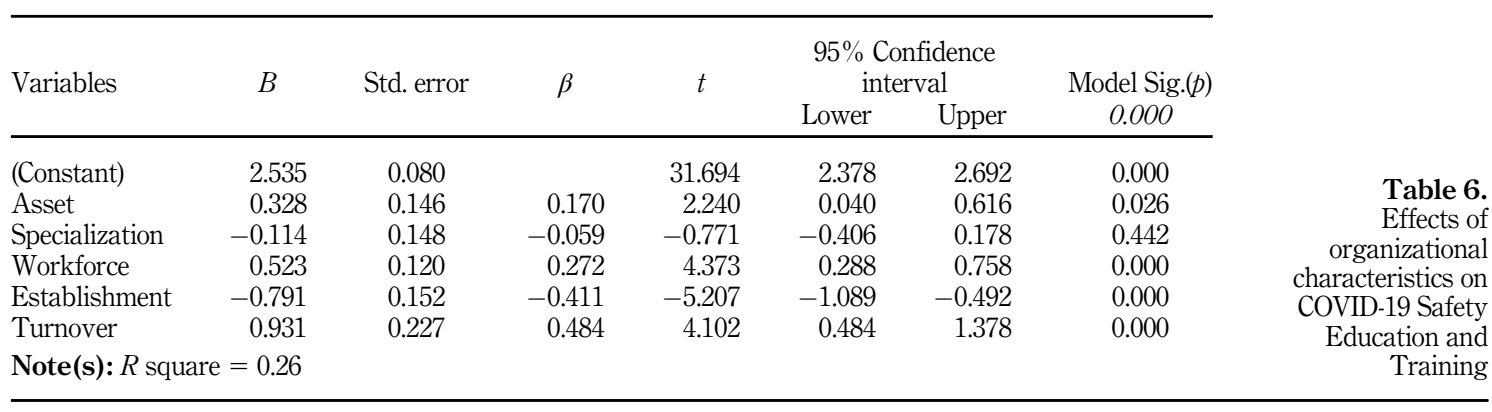

COVID-19 safety practices among SMEs

51

\section{Conclusion and recommendation}

This study investigated the role of organizational characteristics in shaping COVID-19 safety practices among SMEs. Findings revealed that all organizational characteristics except SMEs' area of specialization, are good predictors of the COVID-19 safety practices among SMEs thereby, upholding the three propositions of the study. SMEs' annual turnover and workforce have a positive and significant relationship with COVID-19 safety management practices whereas SMEs' years of establishment have a negative and significant relationship with COVID-19 safety management practices. SMEs workforce is positively associated with 
FEBE 1,1

COVID-19 safety workers commitments. Similarly, SMEs' annual turnover, workforce and assets have a positive and significant relationship with COVID-19 safety education and training whereas SMEs' years of establishment have a negative and significant relationship with COVID-19 safety education and training. Findings revealed that SMEs' areas of specialization do not suggest that COVID-19 safety practices will be adopted. Specifically, newer established SMEs with large turnover and workforce are more likely to adopt COVID19 safety management measures compared to older established SMEs with small turnover and workforce. Workers of SMEs with a large workforce are more likely to observe COVID-19 safety practices than those with a small workforce. Similarly, newer established SMEs with a large turnover, workforce and assets are more likely to train and educate workers on COVID19 safety practices than older established SMEs with a small turnover, workforce and assets. The study, therefore, recommended that procuring entities should consider the organizational characteristics of SMEs in their decision to award construction contracts during the pandemic. The government should introduce a COVID-19 safety compliance certificate and be given to compliant SMEs while erring SMEs to be severely sanctioned. Authorities should create an Anti-COVID-19 Task Force for the construction sector with institutional capacity to enforce COVID-19 regulations.

\section{References}

Abada, I.M. and Okorie, A. (2016), "Nationaal policy on micro, small and medium enterprises and the manufacturing sector in Nigeria, 2007-2016", South East Journal of Political Science, Vol. 2 No. 2, pp. 273-300.

Al Amri, T. and Marey-Pérez, M. (2020), "Impact of Covid-19 on Oman's construction industry", Technium Social Sciences Journal, Vol. 9 No. 1, pp. 661-670.

Ayyagari, M., Beck, T. and Demirguc-Kunt, A. (2007), "Small and medium enterprises across the globe”, Small Business Economics, Vol. 29 No. 4, pp. 415-434.

Bartlett, M.S. (1951), "The effect of standardization on a $\chi^{2}$ approximation in factor analysis", Biometrika, Vol. 38 Nos 3/4, pp. 337-344.

Brooks and Knights (2020), "State and regulatory responses to COVID-19 in Nigeria", available at: https://www.lexology.com/library/detail.aspx?g =afefb8de-48be-4 (accessed 17 December 2020).

Chinowsky, P., Molenaar, K. and Realph, A. (2007), “Learning organizations in construction”, Journal of Management in Engineering, Vol. 23 No. 1, pp. 27-34.

DiMaggio, P.J. and Powell, W.W. (1983), "The iron cage revisited: institutional isomorphism and collective rationality in organizational fields", American Sociological Review, Vol. 48 No. 2, pp. 147-160.

Ezeokoli, F., Okongwu, M. and Fadumo, D. (2020), "Adaptability of COVID-19 safety guidelines in building construction sites in Anambra state, Nigeria", Archives of Current Research International, Vol. 20 No. 4, pp. 69-77.

Federal Republic of Nigeria (2021), Coronavirus Disease (Covid-19) Health Protection Regulations 2021, Nigeria Centre for Disease Control. Federal Republic of Nigeria, available at: https:// covid19.ncdc.gov.ng/media/files/Coronavirus_Disease_COVID19_Health_Protection_ Regulations_2021.pdf (accessed 27 January 2021).

Field, A. (2018), Discovering Statistics Using IBM SPSS Statistics/Andy Field, North American Edition, SAGE Publications.

Fornell, C. and Larcker, D.F. (1981), "Evaluating structural equation models with unobservable variables and measurement error", Journal of Marketing Research, Vol. 18 No. 1, pp. 39-50.

Gbadamosi, A.-Q., Oyedele, L., Olawale, O. and Abioye, S. (2020), "Offsite construction for emergencies: a focus on isolation space creation (ISC) measures for the COVID-19 pandemic", Progress in Disaster Science, Vol. 8, pp. 1-9. 
Gbonegun, V. (2020), "Lagos warns firms against breach of COVID-19 guidelines on building sites", The Guardian, Vol. 9, available at: https://guardian.ng/news/lagos-warns-firms-against-breachof-covid-19-guidelines-at-building-ites/ (accessed 26 October 2020).

Hollingsworth, J. (2020), “Construction safety practices for covid-19”, Professional Safety, Vol. 65 No. 6, pp. 32-34.

Hyams, K.C., Murphy, F.M. and Wessely, S. (2002), "Responding to chemical, biological, or nuclear terrorism: the indirect and long-term health effects may present the greatest challenge", Journal of Health Politics, Policy, and Law, Vol. 27 No. 2, pp. 273-292.

International Labour Organization (2020), "Health and safety at work in the COVID-19 pandemic: a key to reviving the labour market and the economy", International Labour Organization, available at: https://www.ilo.org/budapest/whats-new/WCMS_758853/lang-en/index.htm (accessed 12 February 2021).

Kaiser, H.F. (1970), “A second generation little jiffy”, Psychometrika, Vol. 35 No. 4, pp. 401-415.

Kamal, E.M. and Flanagan, R. (2014), "Key characteristics of rural construction SMEs", Journal of Construction in Developing Countries, Vol. 19 No. 2, pp. 1-13.

Krejcie, R.V. and Morgan, D.W. (1970), "Determining sample size for research activities”, Educational and Psychological Measurement, Vol. 30 No. 3, pp. 607-610.

Lama, T. and Anderson, W.W. (2015), "Company characteristics and compliance with ASX corporate governance principles", Pacific Accounting Review, Vol. 27 No. 3, pp. 373-392.

Lexisnexis (2020), "Don't be penalized because of COVID-19 non-compliance", Insights into the Law in South Africa, available at: https:/www.golegal.co.za/covid-19-non-compliance/ (accessed 17 December 2020).

Maragakis, L.L. (2020), "Coronavirus second wave? Why cases increase”, available at: https://www. hopkinsmedicine.org/health/conditions-and-diseases/coronavirus/first-and-second-waves-ofcoronavirus (accessed 17 December 2020).

McKibbin, W.J. and Fernando, R. (2020), The Global Macroeconomic Impacts of COVID-19: Seven Scenarios, Asian Economic Papers, MIT Press, pp. 1-55.

McNabb, D.E. (2020), Research Methods for Political Science: Quantitative, Qualitative and MixedMethod Approaches, Taylor \& Francis, Routledge \& CRC Press.

Meyer, J.W. and Rowan, B. (1977), "Institutionalized organizations: formal structures as myth and ceremony", American Journal of Sociology, Vol. 83 No. 2, pp. 340-363.

Moser, R., Winkler, J., Narayanamurthy, G. and Pereira, V. (2020), "Organizational knowledgeable responses to institutional pressures - a review, synthesis, and extension", Journal of Knowledge Management, Vol. 24 No. 9, pp. 2243-2271.

Ogunnusi, M., Hamma-Adama, M., Salman, H. and Kouider, T. (2020), "COVID-19 pandemic: the effects and prospects in the construction industry", International Journal of Reconfigurable and Embedded Systems, Vol. 14 No. Special Issue 2, pp. 120-128.

Okafor, C.A. (2007), "Organizational characteristics and performance in Nigerian quoted companies", Research Journal of Business Management, Vol. 1 No. 1, pp. 37-49.

Oliver, C. (1991), "Strategic responses to institutional processes", Academy of Management Review, Vol. 16 No. 1, pp. 145-179.

Olokoyo, S. (1999), Managing Your Small-Scale Enterprises Successfully: A Guide to Entrepreneurs, Managers, and Students, 3rd ed., Ola Jamon Printers and Publishers, Kaduna.

Preskorn, S.H. (2020), "The 5\% of the population at high risk for severe COVID-19 infection is identifiable and needs to be taken into account when reopening the economy", Journal of Psychiatric Practice, Vol. 26 No. 3, pp. 219-227.

Raynard, M., Johnson, G. and Greenwood, R. (2015), "Institutional theory and strategic management", in Advanced Strategic Management: A Multi-Perspective Approach, Red Globe Press. 
FEBE 1,1

Shibani, A., Hassan, D. and Shakir, N. (2020), "The effects of pandemic on construction industry in the UK", Mediterranean Journal of Social Sciences, Vol. 11 No. 6, pp. 48-48.

Shittu, A.A., Ibrahim, A.D., Ibrahim, Y.M., Adogbo, K.J. and Mac-Barango, D.O. (2016), "Impact of organizational characteristics on health and safety practices of construction contractors", Nigerian Journal of Technological Research, Vol. 11 No. 1, pp. 60-67.

Shrestha, N. (2021), "Factor analysis as a tool for survey analysis", American Journal of Applied Mathematics and Statistics, Vol. 9 No. 1, pp. 4-11.

Simpeh, F. and Amoah, C. (2021), "Assessment of measures instituted to curb the spread of COVID-19 on construction site", International Journal of Construction Management, Vol. 21 No. 1, pp. 1-19.

Small and Medium Enterprise Development Agency of Nigeria (SMEDAN) (2015), "National policy on micro, small and medium enterprises", Federal Republic of Nigeria, available at: https://www. smedan.gov.ng/images/PDF/NATIONAL-POLICY-ON-MSMEsNew.pdf (accessed 24 September 2020).

Small and Medium Enterprises Development Agency of Nigeria and National Bureau of Statistics (2017), "National survey of micro small and medium enterprises (MSMEs)", available at: https:// nigerianstat.gov.ng/elibrary?queries[search]=SMEs (accessed 24 September 2020).

World Health Organization (2020), Coronavirus Disease (COVID-19): Health and Safety in the Workplace, available at: https://www.who.int/news-room/q-a-detail/coronavirus-disease-covid19-health-and-safety-in-the-workplace (accessed 24 September 2020).

World Health Organization (2021), Coronavirus Disease (COVID-19) dashboard, World Health Organization, available at: https://covid19.who.int (accessed 15 March 2021).

Zucker, L.G. (1987), "Institutional theories of organization”, Annual Review of Sociology, Vol. 13 No. 1, pp. $443-464$.

\section{About the author}

Samuel Abiodun Alara is a lecturer in the Department of Quantity Surveying, Federal Polytechnic Mubi, Adamawa-Nigeria. Alara holds a Master's degree in Project Management. He is a registered professional with the Financial Reporting Council of Nigeria (FRCN), a corporate member of the Nigerian Institute of Quantity Surveyors (NIQS) and is also registered with the Quantity Surveyors Registration Board of Nigeria (QSRBN). Alara is a Consultant Quantity Surveyor with Y.S Associates; a Consulting Project Management and Quantity Surveying firm that specialize in the management of building and engineering projects. Samuel Abiodun Alara can be contacted at: samuelabiodunalara@gmail.com

For instructions on how to order reprints of this article, please visit our website:

www.emeraldgrouppublishing.com/licensing/reprints.htm

Or contact us for further details: permissions@emeraldinsight.com 